\title{
Global Financial Crisis and the Clamor for a New World Financial Order
}

\author{
- An African Perspective \\ S. Gozie Ogbodo \\ Department of Public Law, Faculty of Law, University of Benin, P.M.B. 1154, \\ Benin City, Nigeria. \\ Tel: 11-234-080-5843-6456 E-mail: gozieogbodo@yahoo.com
}

\begin{abstract}
The Bretton Woods institutions (BWIs) form the core of the world's international financial institutions (IFIs). In the light of the current financial and economic meltdown, the failure of the BWIs to forecast and cushion the impact for member countries, particularly; its graver consequences for developing countries have exposed the inherent weaknesses in the system. Consequently, there has arisen the call for a new world financial order that will be more representative of the world.
\end{abstract}

Keywords: Bretton Woods Institutions (BWIs), International financial institutions (IFIs), Financial and economic meltdown, World financial order, developing countries

\section{Introduction}

Since World War II (Note 1) and its aftermath, the fabric of the world's financial and economic structure has not been threatened to the point of imminent collapse as has been seen recently (Note 2). What started as a mere housing sector meltdown (Note 3) in the United States of America, soon spread the world with varying degrees of the contagion effect (Note 4). As a result of the unpreparedness of the rest of the world to the contagion effect and consequences of the financial crisis, they were hard hit by the crisis. Consequently, panic-induced measures which were hastily formulated failed to stem the tide of the titanic crisis.

Apparently, as the governments of the world economies felt 'ambushed' by the crisis, so did the international financial institutions (hereinafter IFIs), particularly, the Bretton Woods institutions (hereinafter BWIs) (Note 5). Although their mandate and charter charged them to serve as the watchdogs of the world's economic and financial developments, yet they failed to monitor and warn the world of the imminence of a crisis that is so grave and likely to cripple the entire world's economic and financial foundation (Note 6). Such failure on the part of the IFIs and the BWIs in particular, no doubt, has justifiably raised a couple of questions ranging from the utility of the BWIs to their efficacy, if any. Some have wondered also how the BWIs, mostly headquartered in the United States, could have failed to notice such a crisis brewing in their neck of the wood (Note 7). Others have used the opportunity to clamor more vociferously for a re-hauling of the Bretton Woods institutions (BWIs) as presently constituted.

From an African perspective this writer has posited elsewhere (Note 8) that the BWIs were not formed ab initio to serve the primary interest of developing countries in general and Africa, in particular. Such assertion can be justified by the fact that at the formation of the BWIs, most of the developing countries and indeed African countries were politically disenfranchised by colonialism (Note 9). As a result, they were not parties to the conferences which produced the BWIs. Since they were not present neither their interests nor their positions were canvassed and protected at the conferences (Note 10). Consequently, the BWIs as presently constituted are the products of mostly European and American governments while their principal offices are occupied by the representatives of those governments (Note 11).

It is in light of the foregoing that this work will attempt to join the growing army clamoring for a new world financial order that will not only be more responsive to the emerging challenges of the $21^{\text {st }}$ century but will be truly representative of the 'new' world of developing countries in general, and Africa, in particular.

Part II will review the history of the IFIs, particularly the BWIs. Part III will identify and analyze the key factors which gave rise to the present financial crisis. Part IV will focus on the principal way in which most governments have responded to the crisis by taking over majority of the badly affected businesses in their countries. Here, we shall attempt to distinguish benevolent nationalization from the typical kind of nationalization. Part $\mathrm{V}$ will proffer some basis for the clamor of the new world financial order. Part VI will conclude with recommendations aimed at making the new BWIs to be truly representative of the developing countries. 


\section{Evolution of the Bretton Woods institutions (BWIs)}

The BWIs form the core of the class of international financial institution (IFIs) whose functions and responsibilities involve the formulation, regulation and monitoring of the financial and economic policies and development projects which impact the World (Note 12). The evolution of the BWIs began as a matter of necessity in the aftermath of the World War II (Note 13). Upon the cessation of the war, the leaders of the victorious Allied Powers converged in Bretton Woods, New Hampshire, in 1944 under the auspices of the United Nations Monetary and Financial Conference. Cognizant of the vital role that discriminatory trade and economic practices played in causing the war, the leaders were resolved to fashion a comprehensive financial and monetary system that would not just forestall a re-occurrence of war, but spur economic growth.

The conference aimed at creating a tripartite system, namely, the International Monetary Fund (IMF) (Note 14), the International Bank for Reconstruction and Development (IBRD) or the World Bank (Note 15), and the International Trade Organization (ITO) (Note 16). The conference ultimately succeeded in creating the IMF and the World Bank, but failed to create the ITO. Consequently, the general agreements which had been formulated preparatory to the creation of the ITO became, by default, the tripartite system of the BWIs some years later. At subsequent conferences which spanned from 1946 to 1948, the General Agreement on Trade and Tariffs (GATT) was finalized. Conceptually, the original goal was for GATT to be an embodiment of the results of the tariff negotiations, while the ITO would serve as the organizational framework for the implementation of the GATT provisions. As a result of the failure of ITO to materialize (Note 17), under the anomalous GATT regime as both the Agreement and the organization, nation participants were creatively referred to as "contracting parties" rather than as "nations." (Note 18)

While the IMF was created to repair the disintegration of the international monetary system after the war, the World Bank was created to stimulate and support foreign investment which had declined significantly. It is worthy of notation that in the course of their development, both the World Bank and the IMF have collaborated in the enforcement of structural adjustment programs (SAPs) and the imposition of otherwise painful 'conditionalities', respectively (Note 19). The unpopularity of these conditionalities in African countries is understandable in light of their negative implications on "domestic issues as wage rates, levels of public expenditures, budget deficits and export levels." (Note 20) The GATT, however, was intended to help reverse the protectionist and discriminatory practices which tremendously fuelled the war. In the subsequent amendments to GATT, specifically, the eight-year Uruguay Round of Talks (1986-1994), the WTO was formed in 1996 as a full-fledge international organization for the efficient implementation of GATT as was originally envisioned under the ITO. The WTO introduced a couple of innovative provisions which included substantial revisions in the trade dispute settlement procedures, expanded its coverage to include trade in services (GATS), the protection of all trade obligations, as well as the obligation of all member states to abide by all the provisions of the agreements.

As this writer posited earlier, by the end of World War II, most of the countries presently classified as developing were either under colonial rule or just emerging from colonial rule into political independence (Note 21). Consequently, the majority of them still under colonial rule could not attend the Bretton Woods conference, while the few which were emerging from colonial rule lacked the political clout to make substantial inputs at the conference dominated by the leaders of the victorious Allied Powers. Indeed, the final form and shape of the BWIs, ipso facto, reflected substantially the Euro-American interests while the governing structures were (and still is) dominated by their representatives (Note 22). Regardless of the form of the BWIs, it was expected that they will serve as the international watchdog for economic and financial crisis as is presently being experienced.

\section{Crisis Factors}

According to Professor George Walker, "the crisis arose as a result of a combination of factors" (Note 23). He, however, identified five major factors as follows - credit accumulation (and economic bubbles); product complexity, valuation limits, risk separation and liquidity provision (Note 24). Other more general underlying trends, according to him, include financial innovation, securitization and repacking, disintermediation, the privatization of debt and the 'deconstruction of risk.' (Note 25)

\subsection{Credit Accumulation}

The over supply of cheap credit for an unreasonably long period of time, particularly in the United States of America, understandably created "insatiable corporate and household appetite for debt and consumption." (Note 26) The result was that the massive accumulation of credit and debt by households and the corporate world resulted in an inevitable economic and financial burst.

Although the September 112001 terrorist attacks (Note 27) justified the maintenance of low interest rates to spur recovery in the U. S. economy, the rates should have been gradually reviewed as the economy continued to show signs of recovery. Rather, the low and cheap rates were maintained long after the economy recovered until the bubbles burst. 


\subsection{Product Complexity}

As the appetite of the corporate world and the households grew insatiably, so was the corresponding demand on the banks for more debt products. The banks responded by creatively fashioning new and complex debt products.

In addition to the 'formal' banks (Note 28), there arose the 'informal' banks (Note 29) attracted by an apparently insatiable consumer appetite. Working in concert and competition, both banking sectors 'flooded' the economy with an endless variety of cheap debt products. The cycle thus became vicious.

\subsection{Asset Valuation}

The complexity of new financial debt products deprived the banks of the vital and accurate rating of the volatility of such products. Rating agencies (Note 30), though lacking in requisite expertise to correctly rate these products, nevertheless responded to corporate pressures to provide some rating, even if flawed. As a result, otherwise risky and highly volatile debt products were rated unjustifiably high and good. By the time banks like Halifax Bank of Scotland and Royal Bank of Scotland realized the magnitude of their respective exposure, it was too late.

\subsection{Market Risk}

The co-mingling of the relatively new and 'toxic' (Note 31) debt products with the time-tested and proven safe debt products ultimately 'polluted' the entire debt market. This was most apparent in the US economy where the new mortgage securities from the subprime market 'polluted' the rather conventional securities products. For example, it has been estimated (Note 32) that the $\$ 500 \mathrm{bn}$ subprime market was only likely to default by a quarter of the entire portfolio, i.e. $\$ 125 \mathrm{bn}$. However, by co-mingling the 'toxic' subprime product with the time-tested regular products with an estimated value of $\$ 1$ trillion, the entire market became severely infected.

\subsection{Market Support}

In the wake of the crisis, there arose severe scarcity of credit in interbank transactions. The line of credit typically provided by central banks could not adequately cover the deepening credit crunch faced by most banks. As banks scrambled for support in the form of additional credit infusions from their governments, some governments (particularly the US and the UK) were initially reluctant to intervene in what they erroneously thought would be rectified by normal market forces (Note 33). By the time the governments decided to throw credit life-lines at the banks, the economic horse had bolted.

\subsection{Others}

As we pointed out earlier, other contributory factors identified by Professor George Walker include financial innovation, securitization and repacking, disintermediation, the privatization of debt and the 'deconstruction of risk.'(Note 34) This writer strongly believes that with particular respect to the U.S., the prosecution of two wars (Note 35) simultaneously contributed tremendously to the credit crisis. In order to finance both wars which were costing billions of dollars monthly, the U.S. government sucked up facilities in the economy which would otherwise have been available to households and the corporate world. Moreover, the reluctance of the U.S. government to initially intervene, aside from the erroneous diagnosis of the problem, may also have been informed by the already mounting sovereign debt (Note 36) and huge deficit faced by the government.

\section{Crisis Response}

After their initial reluctance (and outright refusal) to 'meddle' in the free market forces, governments intervened, albeit lately, to salvage what was left of their severely battered economies. Due to their belated intervention, by the time they did, palliative measures were grossly inadequate to stem the tide.

In the final analysis, the only viable option was an outright takeover of the businesses whose outright collapse would gravely impact their respective economies. Thus, began what for a lack of better expression, we shall call 'benevolent nationalization.'

\subsection{Benevolent Nationalization}

The general assumption is that it is only in communist or socialist types of government that factors of production are owned and managed by the government. However, under certain circumstances, governments of countries which profess and champion the ideals of free market economies can, and do, takeover the factors of production for a variety of reasons. Infact, as some commentators have rightly opined, "all governments are in business to some degree." (Note 37)

What, therefore, is nationalization? Nationalization is the process whereby governments, in exercise of their economic sovereignty, take over a vital productive sector which had been privately owned and managed. Again, there is a pervasive assumption that such takeovers are 'hostile' because they involve businesses with substantial foreign ownership interests. 
It is in an attempt to distinguish between 'hostile' takeovers (Note 38) and 'non-hostile' takeovers (Note 39) that we have described the latter as benevolent nationalization. The recent examples of governments in Europe and the U.S. taking over very vital businesses in response to the global economic crisis fit the unique type of nationalization process called benevolent nationalization.

\subsection{Nationalization Factors}

Inherent in all nationalization process are some motivating factors; some of them hostile, while others are not. Interestingly, both kinds may be identified simultaneously in any given effort to nationalize a business. The popular factors have been identified to include the following (Note 40):

(4.2.1) To force the firms to pay more taxes from their profits. Inherent in this factor is an overriding suspicion by government that the firm is concealing the exact profit amount. (Note 41)

(4.2.2)Government believes it can run the firm more profitably (Note 42). This factor overlaps with the former one because it is driven by the desire of the government to maximize the profit.

(4.2.3) Ideological reasons. Typically, left-wing governments, communist and socialist governments believe strongly in government takeover of firms, particularly, those whose functions are critical to the welfare of the people (Note 43). Such has been the case in Nigeria, Britain, France, Canada, Venezuela, etc.

(4.2.4.) For political expediency. Political motivations, especially during election year, compel the ruling political party to sustain sometimes unprofitable firms in order to win re-elections. (Note 44)

(4.2.5) To protect government investment in the firm (Note 45). At times, due to the huge amount of money already invested by the government in a firm, it naturally wants to be in control.

(4.2.6) As a consequence of war. Governments, as a price of war, have justified the takeover of firms owned by their enemies. (Note 46) This was the case with the European takeover of German-owned firms after World War II. Similar example was seen in the U.S. after the attacks of September 112001 (Note 47), when the U.S. government nationalized all the firms linked to Al Qaeda and froze all their accounts.

(4.2.7) In response to grave economic and financial crisis (Note 48). Under extremely difficult economic and financial conditions, governments can takeover firms locally owned if such response appears to be the last option to avert the worsening of the national crisis. This is the prevalent response of many governments in Europe and the U.S. under the current global economic crisis which has apparently defied the solutions of the free market forces. This is our classic example of benevolent nationalization. (Note 49)

\section{Case for a new world order}

The need to create a new world financial order in the light of the current financial crisis is premised on a variety of reasons which include political harmony, political dignity, flexibility, re-enforcement, diversification, etc. Let's look at them seriatim.

\subsection{Political harmony}

The current BWIs were creations of post-World War II. The exigencies of the aftermath of the war motivated the creation of these institutions, and greatly influenced their composition and objectives. After over six decades of operation (Note 50), these institutions are faced with a completely 'new' world from the world in existence when they were created (Note 51). Consequently, the scope of their operation has tremendously expanded while their responsibilities have increased exponentially.

Further, as more countries have since then gained their political independence and swelled the rank of these institutions, (with varying degrees of influence), they have consistently clamored for a re-distribution of influence and resources within these institutions. They argue, and rightfully so, that the concept of independence and sovereignty should entail not just participation but some stake in the affairs of these institutions.

More critical is the elimination of what one commentator (Note 52) classified as the 'creditor' mentality and 'debtor' mentality in these institutions which is antithetical to the international collaboration of all member countries critically needed in order to ensure the efficient operation of these institutions. No wonder that in the light of the current financial crisis, the clamor for a new world order has gained tremendous momentum.

\subsection{Political dignity}

Prior to the current financial crisis, the bulk of the work done by these BWIs (particularly the World Bank and IMF) in the past four decades was in developing countries. Thus, most of the policies developed by them were fashioned for the benefit of the developing countries. The most controversial of them all framed as 'conditionalities' for the receipt of financial assistance connotes far-reaching political, social, and economic reforms in the recipient country. Research 
shows that some of the conditionalities have tremendously contributed to the instability and eventual overthrow of some governments in some developing countries.

Critics of these harsh conditionalities have accused the BWIs of insensitivity in the formulation and enforcement of these conditionalities. They allege that the BWIs adopt a one-size-fits-all package which lacks knowledge of the peculiarities of each developing country (Note 53). In order to avert such criticism and ensure the credibility of such reform packages, it is suggested that the input of the recipient country be sought and incorporated in the respective reform package formulated for that country.

\subsection{Flexibility}

Following from the point enumerated above, apart from harnessing political harmony and collaboration, a re-invented world financial order will address the vital issue of flexibility in responding to the evolving roles and challenges constantly faced by such institutions. Take for instance, the World Bank, which upon creation was devoted primarily to the rebuilding of devastated Europe. Since the successful accomplishment of that role, its roles have evolved and will continue to evolve in an ever-changing and dynamic world. The need for flexibility, therefore, can not be over-emphasized. Ditto for the other institutions.

\subsection{Re-enforcement}

A new world financial order which not only takes cognizance of the 'new' world but fully integrates members of that new world into its decision-making organs with equal access to resources and responsibilities will better serve the world. There is no doubt that members from developing countries will enrich these institutions with their human capital thereby re-enforcing the human capital base of these institutions. In the final analysis, both these institutions and the world they serve will be the chief beneficiaries. It is on the basis of this point that the earlier criticism of the Bretton Woods II is premised. A global financial crisis in the magnitude and reach as is currently being experienced demands a truly global approach in the search for a lasting solution(s). It can not be the exclusive preserve and privilege of the few 'elite' countries called the G20.

\subsection{Diversification}

In this context, special cognizance is paid to the chief source of the current global financial crisis - the US economy. The current BWIs and indeed the IFIs are heavily dependent on the well-being of few Western economies, primarily, the economy of the United States of America. Thus, the saying that when the US economy sneezes, the world would catch cold takes a literal meaning. As we stated earlier, the current crisis which emanated initially from the meltdown in the US housing sector spread the entire US economy and the world economy like a wild fire in the harmattan. Such an over-reliance is not safe for the overall well-being of the entire world's economy.

However, if the new world financial order is fashioned in such a way that no country's economy can be so dominant as to literally 'pollute' the entire world economy, it will save the world a repeat of the current crisis on such a global scale.

\section{Conclusion}

The current global economic and financial crisis has starkly exposed the inefficiency of some IFIs, particularly, the BWIs. Not only have they failed in their core function of monitoring the economic and financial developments on a global basis, but they have also failed to monitor such development arising from their neighborhoods in Europe and the U.S.

As a result, world leaders from France, UK, Japan, etc. have called for a new world financial order (Note 54). African countries, and indeed all developing countries, must join in the clamor for the reform of the IFIs, particularly, the BWIs. Such a reform must entail "appropriate institutional or other diplomatic concessions...including amending the composition and voting rights on the IMF, World Bank and other IFIs' boards." (Note 55) The convening of the 'Bretton Woods II' (Note 56), under the auspices of the G20 'Leaders Summit on Financial Markets and the World Economy', it is submitted, was a faulty beginning (Note 57). Such a conference should not have been limited to only the G20 leaders, but should have been convened under the United Nations General Assembly, thereby ensuring a more global participation of all nations.

Understandable that during the original Bretton Woods conference, African participation was limited due to colonialism (Note 58). However, there should be no justification for the continued exclusion of all developing countries (apart from some in attendance as observers), and indeed African countries, under the current Bretton Woods II.

In addition to reforming the BWIs, other reform measures which have been proposed include "financial system revision, regulatory revision, supervisory revision, crisis management revision and institutional revision." (Note 59) It is ironic that the genesis of the current global financial crisis emanated from the U.S. and Europe; yet, the impact is felt in varying degrees in other parts of the world, including Africa (Note 60). Inexplicably, those other parts of the world are excluded in the 'global' search for the solution to the crisis. Hopefully, Bretton Woods II will not be a case of old wine in new bottle. 


\section{References}

Ogbodo, S. Gozie. (2009). The Evolving Roles of certain International Financial Institutions in Developing Countries under International Law in C.C. Nweze (Ed.), Contemporary Issues on Public International and Comparative Law, Vandeplas Publishing.

Gianviti, F., (2001). Evolving Role and Challenges for the International Monetary Fund. THE INTERNATIONAL LAWYER, Volume 35, Number 4, pg 1398.

Garcia, F.J. (2007). Global Justice and the Bretton Woods Institutions, JIEL (461)

Walker, George (2009). Credit Crisis, Bretton Woods II and new global response :pt 2, 2 JIBFL 77, p.2

Ball, McCulloch, et al; (1998). International Business: The Challenge of Global Competition. McGraw-Hill Irwin, $8^{\text {th }}$ ed, p. 353

\section{Notes}

Note 1. World War II (1939-1945) was fought between the victorious Allied Powers and the Axis Powers. The Allied Powers comprised of major players like the United States of America, United Kingdom, France, Soviet Union and China. The Axis Powers, on the other hand, comprised major players like Germany, Japan and Italy. Although the Allied Powers won, yet; it is estimated that the war cost them over seventeen million of their military personnel and over thirty three million civilians. On the contrary, the Axis Powers lost an estimated eight million military personnel and over twelve million civilians.

Note 2. From London to New York to Japan, the present global financial crisis has rocked the foundation of the world's major financial and economic pillars. In all these economies, unemployment has hit double digits while most banks are struggling to survive and others have collapsed.

Note 3. The subprime mortgage defaults in the US heralded what turned out to be a global economic and financial crisis of unimaginable proportions.

Note 4. Contagion effect in this context connotes the pollution of other sectors and economies by the 'toxic' subprime mortgage defaults in the U.S.

Note 5. International financial institutions (IFIs) comprise of all the international organizations whose mandate is to formulate, monitor and enforce financial policies on a global scale. The major component is the Bretton Woods institutions (BWIs) which are the IMF and the World Bank. The WTO, although replacing the originally conceived ITO under the Bretton Woods model was birthed in 1996.

Note 6. Article IV, section 3 of the Articles of Agreement of the IMF specifically provides for the surveillance function of the Fund. Section 3 provides that (a) The Fund shall oversee the international monetary system in order to ensure its effective operation, and shall oversee the compliance of each member with its obligations under Section 1 of this Article. (b) In order to fulfill its functions under (a) above, the Fund shall exercise firm surveillance over the exchange rate policies of members, and shall adopt specific principles for the guidance of all members with respect to those policies. Available at http://www.imf.org/external/about/histcoop.htm.

Note 7. The World Bank and IMF are both headquartered in the US while the WTO is headquartered in Europe.

Note 8. See Ogbodo, S. Gozie (2009). The Evolving Roles of certain International Financial Institutions in Developing Countries under International Law in C.C. Nweze (Ed.), Contemporary Issues on Public International and Comparative Law, Vandeplas Publishing, 2009.

Note 9. Colonialism of African states deprived them of their respective sovereignties. As a result, those under colonialism could not participate as sovereign states during the Bretton Woods conferences. Many African countries swelled the membership of both the IMF and World Bank beginning from the 1950s and 1960s when many of them gained their political independence.

Note 10. Ibid

Note 11. Since the formation of the World Bank and the IMF, the head of each of them have been Americans and Europeans, respectively. The Presidents of the World Bank since creation are as follows: Eugene Meyer (June 1946 December 1946), John J. McCloy (March 1947 - June 1949), Eugene R. Black (July 1949 - December 1962), George D. Woods (January 1963 - March 1968), Robert S. McNamara (April 1968 - June 1981), Alden W. Clausen (July 1981 - June 1986), Barber Conable (July 1986 - August 1991), Lewis Preston (September 1991 - May 1995), James D. Wolfensohn (June 1995 - May 2005), Paul Wolfowitz (June 2005 - June 2007) and Robert B. Zoellick (June 2007 present). See http://web.worldbank.org/WBSITE/EXTERNAL/EXTABOUTUS/EXTARCHIVES/O. The Managing Directors of the IMF since creation are as follows: Camille Gutt from Belgium (May 6, 1946 - May 5, 1951), Ivar Rooth from Sweden (August 3, 1951 - October 3, 1956), Per Jacobsson from Sweden (November 21, 1956 - May 5, 
1963), Pierre-Paul Schweitzer from France (September 1, 1963 - August 31, 1973), H. Johannes Witteveen from the Netherlands (September 1, 1973 - June 16, 1978), Jacques de Larosiere from France (June 17, 1978 - January 15, 1987), Michel Camdessus from France (January 16, 1987 - February 14, 2000), Horst Kohler from Germany (May 1, 2000 - March 4, 2004), Rodrigo de Rato from Spain (June 7, 2004 - October 31, 2007), Dominique Strauss-Kahn from France (November 1, 2007 - present). See http://www.imf.org/external/np/exr/chron/mds.asp

Note 12. The BWIs comprise of the IMF which is an intergovernmental organization of 186 countries. It was created in July 1944 when representatives of 45 countries met in Bretton Woods, New Hampshire in the US for that purpose. See http://www.imf.org/external/about/histcoop.htm. Same for the World Bank which became effective on December 31, 1945. Its current membership is also 186 countries. See http://web.worldbank.org/WBSITE/EXTERNAL/EXTABOUTUS/O.

Note 13. Note 1, supra, on World War II.

Note 14. The IMF was created in July 1944 with the mandate to "foster global monetary cooperation, secure financial stability, facilitate international trade, promote high employment and sustainable economic growth, and reduce poverty around the world." See http://www.imf.org/external/about/histcoop.htm

Note 15. The World Bank started the formation of one of its two primary lending organs, the International Bank for Reconstruction and Development (IBRD) in 1945. Its original mission was to facilitate the reconstruction of Europe. Later, it expanded its mission to facilitating development lending at preferential rates. The other lending organ, the International Development Association (IDA), was formed in 1960 to facilitate development in the poorest countries of the world by providing them lending facilities at concessional (zero-interest) rates and grants. See http://siteresources.worldbank.org/EXTARCHIVES/Resources/WB_Historical_Chronology_1944_2005.pdf.

Note 16. The ITO suffered a "still birth" when the US government at the time failed to secure the support of the US Congress to authorize the President to ratify the ITO draft Agreement.

Note 17. Ibid

Note 18. In the absence of an organization envisioned under the ITO, the surviving GATT lacked the character of an international organization, thus nation participants were referred to as "contracting parties."

Note 19. The World Bank's Structural Adjustment Programs (SAPs) and the IMF's conditionalities work simultaneously by insisting on domestic policy reforms in the beneficiary countries. According to the IMF, conditionality is the link between the approval or continuation of the Fund's financing and the implementation of specified elements of economic policy by the country receiving the financing. See IMF, "Conditionality in Fund-Supported Programs - Overview" http://www.imf.org/external/np/pdr/cond/2001/eng/overview/index.htm, cited by Garcia, F.J. (2007). Global Justice and the Bretton Woods Institutions, JIEL (461)

Note 20. See Garcia, F.J., ibid

Note 21. See note 8, supra, Ogbodo, S. Gozie (2009). The Evolving Roles of certain International Financial Institutions in Developing Countries under International Law. See also note 9, supra, on colonialism of African states.

Note 22. See note 11 which lists all the past and current leaders of both the IMF and the World Bank. All of them, past and present, are either Americans or Europeans. The voting power of all African countries in the highest organs of both institutions is also negligible notwithstanding the current population of African countries in these institutions. For instance, the actual voting power of all African countries on the Executive Board of the IMF is less than 5\% of the total votes. See http://www.imf.org/external/np/see/memdir/eds.htm.

Note 23. See Walker, George (2009). Credit Crisis, Bretton Woods II and new global response :pt 2, 2 JIBFL 77, p.2

Note 24. Ibid, Walker, George (2009) p.2

Note 25. Ibid, Walker, George (2009) p.2

Note 26. Ibid, Walker, George (2009) p.2

Note 27. On September 11, 2001, coordinated attacks were carried out on the US by terrorists linked to Al Qaeda group, led by Osama bin Laden. The twin towers of the World Trade Center in New York and the military headquarters of the US called the Pentagon were destroyed. Thousands of lives were also lost in the attacks. The US government reacted by waging wars on Afghanistan and later on Iraq, for harboring Osama bin Laden and for allegedly supporting Al Qaeda, respectively.

Note 28. 'Formal' banks included the commercial and mortgage banks.

Note 29. 'Informal' banks were the money-lending shops and kiosks which arose in the lucrative era of cheap lending and huge profit.

Note 30. Financial products and securities are typically subjected to a rating process by the rating agencies. 
Note 31. See Walker, George (2009), note 23, supra, p.4

Note 32. Ibid, Walker, George (2009) p.3

Note 33. This was the case of the US government when, initially, then President George Bush insisted that government will not intervene in the free working of the market forces.

Note 34. See Walker, George (2009), note 23, supra, p.2

Note 35. See the September 11, 2001 terrorist attacks on the US, note 27, supra

Note 36. Sovereign debt is the total outstanding debt owed by a country as a sovereign state.

Note 37. See Ball, McCulloch, et al; (1998). International Business: The Challenge of Global Competition, McGraw-Hill Irwin, $8^{\text {th }}$ ed, p. 353.

Note 38. 'Hostile' in this context is used to describe the government takeover of businesses with substantial foreign ownership interests as well as cases where the action is retaliatory.

Note 39. 'Non-hostile', on the contrary, is driven by benevolence and purely self-survival of the government.

Note 40. See Ball, McCulloch, et al; (1998) 37, supra

Note 41. This factor is most apparent in the nationalization of firms substantially owned by foreign interests. Government's desire to 'capture' maximum tax benefits informs such a takeover.

Note 42. This factor is an extension of the former because it is driven by the same desire to maximize the profits from the business.

Note 43. This factor is motivated purely by left-wing political ideology which is mostly at variance with the capitalist ideology. While the former is people-oriented, the latter is profit-oriented.

Note 44. This factor is driven by the short-term goal to survive politically. Typically in an election year, the government's desire to win re-election overrides all other considerations.

Note 45 . Under equity participation or joint venture agreements, governments do invest heavily in some businesses.

Note 46. Foreign owned businesses, particularly, those owned by enemy countries can, and do suffer as a result of war.

Note 47. See the September 11, 2001 terrorist attacks on the US, note 27, supra

Note 48. This factor is informed by non-hostile consideration. The government's response is essentially driven by self survival instincts.

Note 49. See 'non-hostile' takeover in note 39 , supra

Note 50. The Bretton Woods institutions (IMF and World Bank) were created in 1945 in Bretton Woods, New Hampshire, in the United States of America.

Note 51. The World Bank has grown in membership from 44 countries in 1944 to 186 countries in 2009. See http://web.worldbank.org/WBSITE/EXTERNAL/EXTABOUTUS/O.htm. The International Monetary Fund on the contrary has grown in membership from 29 countries in 1945 to 186 countries in 2009. See http://www.imf.org/external/about/history.htm.

Note 52. Gianviti, F., (2001). Evolving Role and Challenges for the International Monetary Fund. THE INTERNATIONAL LAWYER, Volume 35, Number 4, pg 1398. The author emphasized that "Once countries see themselves as creditors or debtors, they tend to have a polarized view of financial assistance...In discussions on the design of Fund facilities, 'creditor countries' may argue for higher costs and shorter maturities of Fund assistance against 'debtor countries,' which want to preserve the status quo."

Note 53. See Ogbodo, S. Gozie (2009), note 8, supra, where this writer amplified the inefficiency of such one-size-fits-all approach.

Note 54. Such calls added to the urgency to convene the G20 'Leaders Summit on Financial Markets and the World Economy' (otherwise called 'Bretton Woods II') which held in Washington DC on 14-15 November 2008.

Note 55. See Walker, George (2009), note 23, supra

Note 56. Bretton Woods II was coined from the original Bretton Woods conference which gave birth to the World Bank and IMF.

Note 57. First, the original Bretton Woods conference was convened under the auspices of the United Nations, thus, providing all sovereign nations at the time the opportunity to attend. The limitation of Bretton Woods II to only the G20 countries and some invited guests is unfair to other countries.

Note 58. See the colonialism of African states in note 9, supra 
Note 59. See Walker, George (2009), note 23 supra, p. 5

Note 60. According to Donald Kaberuka, President of African Development Bank (ADB), "For us, this is not a financial crisis: we're not having a banking crisis, we're having an economic crisis. It's affecting countries through exports, through remittances and through neighborhood effects." Oliver Buston, European Director of ONE (a global advocacy organization), also re-echoed the urgency of the situation when he said that "....Urgent action is now needed from the World Bank to protect the billion poorest people on the planet who had no part in creating the economic crisis but who will be hit the hardest." See Newswatch magazine of May 11, 2009, pgs 36-38 